\title{
Predicting the subcellular localization of viral proteins within a mammalian host cell
}

\author{
MS Scott ${ }^{1}$, R Oomen ${ }^{2}$, DY Thomas ${ }^{3}$ and MT Hallett*1
}

Address: ${ }^{1}$ McGill Center for Bioinformatics, McGill University, 3775 University Street, Montreal, Quebec, Canada, ${ }^{2}$ Integrated Genomics, Sanofi Pasteur, 1755 Steeles Avenue West, Toronto, Ontario, Canada and ${ }^{3}$ Biochemistry Department, McGill University, McIntyre Medical Sciences Building, 3655 Promenade Sir William Osler, Montreal, Quebec, Canada

Email: MS Scott - michelle.scott@mail.mcgill.ca; R Oomen - ray.oomen@sanofipasteur.com; DY Thomas - david.thomas@mcgill.ca; MT Hallett* - hallett@mcb.mcgill.ca

* Corresponding author

Published: 04 April 2006

Virology Journal 2006, 3:24 doi:10.1186/1743-422X-3-24

This article is available from: http://www.virologyj.com/content/3/I/24

(c) 2006 Scott et al; licensee BioMed Central Ltd.

This is an Open Access article distributed under the terms of the Creative Commons Attribution License (http://creativecommons.org/licenses/by/2.0), which permits unrestricted use, distribution, and reproduction in any medium, provided the original work is properly cited.
Received: 22 December 2005

Accepted: 04 April 2006

\begin{abstract}
Background: The bioinformatic prediction of protein subcellular localization has been extensively studied for prokaryotic and eukaryotic organisms. However, this is not the case for viruses whose proteins are often involved in extensive interactions at various subcellular localizations with host proteins.

Results: Here, we investigate the extent of utilization of human cellular localization mechanisms by viral proteins and we demonstrate that appropriate eukaryotic subcellular localization predictors can be used to predict viral protein localization within the host cell.

Conclusion: Such predictions provide a method to rapidly annotate viral proteomes with subcellular localization information. They are likely to have widespread applications both in the study of the functions of viral proteins in the host cell and in the design of antiviral drugs.
\end{abstract}

\section{Background}

Viruses use the host synthetic machinery to replicate. They have evolved mechanisms to exploit the host nucleic acid replication and protein translation apparatus and have also developed strategies to evade humoral immune surveillance. Viral proteins require targeting to the appropriate subcellular compartments of the host cell to fulfill their roles. Viral proteins have been shown experimentally to be localized in many different cellular compartments including the nucleus (for example the protein kinase encoded by Epstein-Barr Virus [1]), the nucleolus (such as the rev and tat proteins from human immunodeficiency virus type 1 [2]), the cytosol (for example the superoxide dismutase-like protein from vaccinia virus [3]), the ER/ Golgi apparatus (for example, the US2 and US1 1 cytome- galovirus proteins $[4,5])$, the plasma membrane and cell surface (cytomegalovirus gp34 glycoprotein [6]), and the mitochondria $(\mathrm{M} 11 \mathrm{~L}$ protein from the myxoma virus and several others, reviewed in $[7,8])$. Targeting to the extracellular space is also observed (for example, cowpox growth factor [9] and the myxoma M-T7 protein [10]).

Protein subcellular localization prediction has been widely studied (reviewed in $[11,12]$ ). Available predictors differ in many aspects including the computational method used, the type and diversity of protein characteristics considered for the prediction, the localization coverage, the target organism(s) and the reliability. Predictors can be grouped into four general classes based upon the protein characteristics that are considered: amino acid 
Table I: Usage of targeting signals in human and viral proteins

\begin{tabular}{|c|c|c|c|c|}
\hline Organism & Human & $\begin{array}{c}\text { Cytomegalovirus (strain } \\
\text { ADI69) }\end{array}$ & Vaccinia (Copenhagen strain) & \\
\hline Protein count & 28908 & 192 & 255 & \\
\hline Targeting signals & \multicolumn{3}{|c|}{ Percentage of proteins containing signal } & Predictor \\
\hline Signal peptide & $22.0 \%$ & $25.0 \%$ & $12.9 \%$ & SignalP [16] \\
\hline Signal anchor & $5.9 \%$ & $8.8 \%$ & $5.9 \%$ & SignalP \\
\hline $\begin{array}{l}\text { Mitochondrial targeting } \\
\text { peptide }\end{array}$ & $8.5 \%$ & $12.0 \%$ & $7.1 \%$ & Predotar [40] \\
\hline $0 \mathrm{TMD}^{\mathrm{a}}$ & $78.0 \%$ & $66.1 \%$ & $76.5 \%$ & TMHMM [4I] \\
\hline I TMDa & $10.0 \%$ & $19.8 \%$ & $16.1 \%$ & TMHMM \\
\hline 2 TMDs $^{\mathrm{a}}$ & $2.4 \%$ & $5.7 \%$ & $5.9 \%$ & TMHMM \\
\hline$>2 \mathrm{TMDs}^{\mathrm{a}}$ & $9.7 \%$ & $8.3 \%$ & $0.8 \%$ & TMHMM \\
\hline GPI anchor & $2.5-3.0 \% \mathrm{~b}$ & $3.1 \%$ & $2.4 \%$ & GPI-SOM [42] \\
\hline Prenyl group (PS00294) & $0.8 \%$ & $0.5 \%$ & $0 \%$ & Prosite [43] \\
\hline NLS & $13.3 \% c$ & $8.3 \%$ & $2.0 \%$ & PredictNLS [44] \\
\hline KDEL-like (PSO00I4) & $0.2 \%$ & $0 \%$ & $0 \%$ & Prosite \\
\hline $\begin{array}{l}\text { Peroxisomal targeting } \\
\text { (PS00342) }\end{array}$ & $2.2 \%$ & $1.6 \%$ & $2.8 \%$ & Prosite \\
\hline $\begin{array}{c}\text { Most prevalent } \\
\text { eukaryotic functional } \\
\text { domains }\end{array}$ & \multicolumn{3}{|c|}{ Percentage of proteins containing domain } & Predictor \\
\hline $\begin{array}{l}\text { Immunoglobulin-like } \\
\text { (IPR007I I0) }\end{array}$ & $2.7 \%$ & $5.7 \%$ & $2.0 \%$ & InterPro [28] \\
\hline $\begin{array}{l}\text { Galactose oxidase } \\
\text { (IPROI I043) }\end{array}$ & $0.3 \%$ & $0 \%$ & $1.6 \%$ & InterPro \\
\hline $\begin{array}{l}\text { Proteinase inhibititor 14, } \\
\text { serpin (IPR0002 I5) }\end{array}$ & $0.2 \%$ & $0 \%$ & $1.6 \%$ & InterPro \\
\hline $\begin{array}{l}\text { Rhodopsin-like GPCR } \\
\text { superfamily (IPR000276) }\end{array}$ & $2.8 \%$ & $2.1 \%$ & $0 \%$ & InterPro \\
\hline
\end{tabular}

a TMD: transmembrane domain

bestimation for proportion of human proteins containing a GPI anchor from [42]

cestimation for proportion of human proteins containing an NLS (nuclear localization signal) from [44].

composition and order based predictors [13-15], sorting signal predictors $[16,17]$, homology based predictors $[18,19]$ and hybrid methods that integrate several sources of information to predict localization [20-23].

Although numerous protein localization predictions exist for whole prokaryotic and eukaryotic proteomes, no such predictions are available for many viral proteins, which are often involved in extensive interactions with host proteins in various subcellular localizations in the host cell. This is surprising as such predictions would be of great use in the study of infectious diseases in order to increase our understanding of the role of these proteins in host cells and could also be useful for the design of improved therapeutic interventions.

Here, we investigate the intracellular localization predictions of viral proteins in human cells. We focus on two viruses, vaccinia virus and human cytomegalovirus, because they infect human cells and have relatively large but well characterized genomes. We show that these viral proteomes harbour many known eukaryotic targeting sig- nals and domains which probably allow them to exploit cellular localization mechanisms. We also use the PSLT human localization predictor [22] to demonstrate that an appropriately chosen predictor can accurately predict the intracellular localization of viral proteins in human cells. Our viral subcellular localization predictions are available as additional files.

\section{Results \\ Eukaryotic targeting signals and functional domains in specific viral proteomes}

In order to investigate the extent of eukaryotic targeting signal usage by the viral proteins considered, we scanned the human, vaccinia virus and cytomegalovirus proteomes using various bioinformatics predictors that identify these signals. To avoid redundancy in the datasets, we considered all proteins available in UniProt [24] from one representative strain of each virus (we chose the AD169 strain for the cytomegalovirus and the Copenhagen strain for the vaccinia virus). As shown in Table 1, despite differences in genome size of several orders of magnitude, several targeting signals are found to a similar extent in both 
Table 2: Subcellular localization prediction of vaccinia virus proteins

\begin{tabular}{|c|c|c|c|c|c|c|}
\hline Gene & $\begin{array}{l}\text { SwissProt } \\
\text { Accession }\end{array}$ & $\begin{array}{c}\text { PSLT } \\
\text { predictions }^{\mathrm{a}}\end{array}$ & $\begin{array}{c}\text { Literature } \\
\text { annotations }\end{array}$ & $\begin{array}{l}\text { Localization } \\
\text { References }\end{array}$ & $\begin{array}{c}\text { Closest human } \\
\text { homologue }^{b}\end{array}$ & $\begin{array}{l}\text { BLAST } \\
\text { e-value }\end{array}$ \\
\hline$A 34 R$ & P21057 & PM & Golgi & {$[45]$} & C-type lectin (NP_072092) & 0.02 \\
\hline$A 38 L$ & P2106I & PM & PM & [46] & CD47 antigen (NP_00I768) & $3 \mathrm{E}-22$ \\
\hline$A 39 R$ & P21062 & Secreted and PM & Secreted & {$[47]$} & semaphorin 7A (NP_003603) & IE-30 \\
\hline$A 40 R$ & P21063 & PM & PM & {$[48]$} & lectin-like receptor (NP_03|359) & $2 \mathrm{E}-9$ \\
\hline$B / 3 R$ & P2084I & Secreted & Cytoplasmic & [49] & $\begin{array}{l}\text { plasminogen activator inhibitor-2 } \\
\text { (NP_002566) }\end{array}$ & $5 \mathrm{E}-7$ \\
\hline$B / 5 R$ & P211116 & Secreted and PM & PM or secreted & {$[50]$} & interleukin I receptor (NP_775465) & $4 \mathrm{E}-32$ \\
\hline$B / 8 R$ & P21076 & $\begin{array}{l}\text { Cytosolic and } \\
\text { nuclear }\end{array}$ & Secreted and PM & {$[51]$} & Ankyrin 3 isoform I (NP_066267) & IE-9 \\
\hline$B 5 R$ & P2III5 & Secreted and PM & PM and Golgi & {$[45,52,53]$} & $\begin{array}{l}\text { coagulation factor XIII B } \\
\text { (NP_001985) }\end{array}$ & $6 \mathrm{E}-17$ \\
\hline$C / 2 L$ & P20531 & Secreted & Secreted & {$[54]$} & $\begin{array}{l}\text { serine proteinase inhibitor } \\
\text { (NP_002965) }\end{array}$ & $4 \mathrm{E}-47$ \\
\hline$C 2 L$ & P21037 & $\begin{array}{l}\text { Nuclear and } \\
\text { cytosolic }\end{array}$ & Cytoplasmic & {$[55]$} & kelch-like 10 (NP_689680) & le-024 \\
\hline$D 8 L$ & P20508 & PM & PM & {$[56]$} & carbonic anhydrase XIII (NP_940986) & $8 \mathrm{E}-35$ \\
\hline$A 45 R$ & P21132 & Cytosolic & Cytoplasmic & [3] & superoxide dismutase I (NP_000445) & $3 \mathrm{E}-6$ \\
\hline$D 4 R$ & P20536 & $\begin{array}{l}\text { Nuclear and } \\
\text { mitochondrial }\end{array}$ & Cytoplasmic & [56] & - & $>0.1$ \\
\hline D6R & P20634 & Nuclear & Perinuclear & {$[58]$} & hypothetical protein (NP_060139) & 0.027 \\
\hline E9L & P20509 & Nuclear & Cytoplasmic & {$[57]$} & polymerase alpha (NP_058633) & $9 E-19$ \\
\hline$E 3 L$ & P2108I & Nuclear & Nuclear & [59] & adenosine deaminase (NP_00II02) & $4 \mathrm{E}-6$ \\
\hline$F I 7 R$ & P68454 & $\begin{array}{l}\text { Cytosolic and } \\
\text { nuclear }\end{array}$ & Cytoplasmic & {$[60]$} & - & $>0.1$ \\
\hline F4L & P20493 & Cytosolic & Cytoplasmic & {$[57]$} & $\begin{array}{c}\text { ribonucleotide reductase M2 } \\
\text { (NP_00|1025) }\end{array}$ & $|E-| 43$ \\
\hline$A 56 R$ & P20978 & PM & PM & {$[61]$} & $\begin{array}{l}\text { dentin matrix acidic phosphoprotein } \\
\text { (NP_004398) }\end{array}$ & 0.015 \\
\hline KIL & P20632 & $\begin{array}{l}\text { Cytosolic and } \\
\text { nuclear }\end{array}$ & Cytoplasmic & [62] & ankyrin 2 (NP_00I I39) & IE-9 \\
\hline$K 2 L$ & P20532 & Secreted & $\begin{array}{l}\text { Extracellularly } \\
\text { associated with } \\
\text { infected cell }\end{array}$ & [63] & $\begin{array}{l}\text { plasminogen activator inhibitor-I } \\
\text { (NP_000593) }\end{array}$ & $3 \mathrm{E}-35$ \\
\hline$M I L$ & P20640 & $\begin{array}{l}\text { Cytosolic and } \\
\text { nuclear }\end{array}$ & Cytoplasmic & [64] & ankyrin 3 (NP_066267) & $4 \mathrm{E}-13$ \\
\hline$C I I R$ & P20494 & PM and secreted & Secreted & {$[65]$} & epiregulin (NP_00I423) & $2 \mathrm{E}-10$ \\
\hline
\end{tabular}

a In the case of multi-compartmental proteins (proteins that are predicted with high probability to be present in more than one compartment), the two most likely compartments were retained by PSLT. PM: plasma membrane.

b The closest human homologue was determined by using BLAST [38] against the NCBI human RefSeq dataset. We do not report a homologue when the BLAST e-value exceeds 0.I.

viral and human proteomes. In particular, large numbers of these viral proteins contain $\mathrm{N}$-terminal signal peptides and anchors, consistent with the knowledge that many glycoproteins encoded in these large viruses require entry into the secretory pathway and have evolved to modulate ER quality control mechanisms to ensure that large quantities of viral proteins can be correctly produced and assembled into infectious particles [25]. Similarly, a high proportion of viral proteins are predicted to contain at least one transmembrane domain. This reflects the high degree of interaction of these enveloped viruses with cellular membranes for functions that include assembly of viral particles and budding of the virus [26], and thus the need for insertion of a large proportion of their proteins in membranes, to participate in and modulate these proc- esses. The vaccinia virus and cytomegalovirus proteomes also contain proteins that are predicted to harbor mitochondrial targeting peptides. Both cytomegalovirus and vaccinia virus are known to encode at least one protein that is localized to mitochondria, where they play a role in the inhibition of apoptosis [7]. GPI anchors, which allow the attachment of proteins to the extracellular leaflet of the plasma membrane, are also predicted to be used by these viral proteins, to a similar extent as by human proteins. This might constitute a significant viral localization mechanism. In contrast to the relatively large proportion of viral proteins harbouring a C-terminal GPI-attachment region, very few of these viral proteins are predicted to be prenylated, which might reflect a greater need for extracel- 
Table 3: Subcellular localization prediction of cytomegalovirus proteins

\begin{tabular}{|c|c|c|c|c|c|c|}
\hline Gene & $\begin{array}{l}\text { SwissProt } \\
\text { Accession }\end{array}$ & $\begin{array}{c}\text { PSLT } \\
\text { predictions }\end{array}$ & $\begin{array}{c}\text { Literature } \\
\text { annotations }\end{array}$ & $\begin{array}{c}\text { Localization } \\
\text { References }\end{array}$ & Closest human homologue & $\begin{array}{l}\text { BLAST } \\
\text { e-value }\end{array}$ \\
\hline$g p 34$ & $\mathrm{PI} 6809$ & PM & PM & [6] & - & $>0.1$ \\
\hline ULI I IA & $\mathrm{PI} 17150$ & Secreted & Secreted & {$[36]$} & interleukin 10 (NP_000563) & $2 \mathrm{E}-9$ \\
\hline ULII4 & PI6769 & Nuclear & Nuclear & [66] & $\begin{array}{c}\text { uracil-DNA glycosylase } \\
\text { (NP_550433) }\end{array}$ & $5 \mathrm{E}-39$ \\
\hline ULII8/II9 & PI6739 & PM & PM & {$[6]$} & - & $>0.1$ \\
\hline ULI8 & P08560 & PM/secreted & PM & [67] & $\begin{array}{l}\text { MHC class lb antigen } \\
\quad(\text { NP_005507) }\end{array}$ & $4 \mathrm{E}-16$ \\
\hline UL33 & PI6849 & PM & $\begin{array}{c}\text { PM, endosomes, } \\
\text { secretory } \\
\text { pathway, } \\
\text { perinuclear }\end{array}$ & {$[34,68]$} & $\begin{array}{l}\text { chemokine receptor I } \\
(\text { NP_00I286) }\end{array}$ & $3 \mathrm{E}-2 \mathrm{I}$ \\
\hline UL48 & PI6785 & Cytosolic and ER & $\begin{array}{l}\text { ER, cytosolic, } \\
\text { vacuolar }\end{array}$ & {$[69,70]$} & $\begin{array}{l}\text { spen homolog, transcriptional } \\
\text { regulator (NP_0558|6) }\end{array}$ & 0.082 \\
\hline UL54 & P08546 & Nuclear & Nuclear & [7I] & polymerase delta I (NP_002682) & $3 \mathrm{E}-50$ \\
\hline UL78 & PI675I & PM & PM & [34] & $\begin{array}{c}\text { somatostatin receptor } 3 \\
\text { (NP_001042) }\end{array}$ & 0.006 \\
\hline UL97 & PI6788 & PM, cytosolic & $\begin{array}{l}\text { Golgi, nuclear and } \\
\text { cytosolic }\end{array}$ & {$[72]$} & - & $>0.1$ \\
\hline USIO & P09728 & PM & ER & [33] & - & $>0.1$ \\
\hline USII & P09727 & PM & ER & [4] & - & $>0.1$ \\
\hline US2 & P097I3 & PM & ER and cytosolic & [5] & - & $>0.1$ \\
\hline US27 & P09703 & PM & $\begin{array}{l}\text { PM, endosomes, } \\
\text { secretory } \\
\text { pathway, } \\
\text { perinuclear }\end{array}$ & {$[34,68]$} & $\begin{array}{c}\text { chemokine receptor I } \\
\text { (NP_00|328) }\end{array}$ & $7 \mathrm{E}-31$ \\
\hline US28 & P69332 & PM & PM, endosomes & {$[34,68]$} & $\begin{array}{l}\text { chemokine receptor I } \\
\text { (NP 001328) }\end{array}$ & $2 \mathrm{E}-55$ \\
\hline US3 & P097I2 & PM & ER & {$[73,74]$} & - & $>0.1$ \\
\hline US6 & $\mathrm{PI} 4334$ & PM & ER & {$[75]$} & - & $>0.1$ \\
\hline US7 & P0973। & PM & ER & [33] & - & $>0.1$ \\
\hline US8 & P09730 & PM & Golgi & [33] & - & $>0.1$ \\
\hline US9 & P09729 & Secreted & ER & [33] & - & $>0.1$ \\
\hline
\end{tabular}

\footnotetext{
a In the case of multi-compartmental proteins (proteins that are predicted with high probability to be present in more than one compartment), the two most likely compartments were retained by PSLT. PM: plasma membrane; ER: endoplasmic reticulum.

b The closest human homologue was determined by using BLAST [38] against the NCBI human RefSeq dataset. We do not report a homologue when the BLAST e-value exceeds 0.I.
}

lular rather than intracellular anchoring of these viral proteins in the plasma membrane.

Nuclear localization signals (NLSs) can also be detected in the viral proteomes. A larger proportion of cytomegalovirus proteins are predicted to contain NLSs than those encoded by the vaccinia virus genome. This is consistent with the fact that the cytomegalovirus genome replication as well as its viral core and capsid assembly occur in the nucleus whereas the vaccinia virus coordinates these processes in the cytoplasm.

We also detected the presence of short targeting signals in these proteomes. The N-terminal KDEL-like endoplasmic reticulum (ER) retrieval motif that is present in approximately $20 \%$ of human ER lumenal proteins [27] does not seem to be used by these viral proteins but the highly nonspecific peroxisomal-targeting signal is present to the same extent in these viral and human proteins.
The most prevalent functional eukaryotic domains present in these viral proteins are also shown in Table 1, as predicted by InterPro [28]. The immunoglobulin-like domain is the most widely used eukaryotic domain in both cytomegalovirus and vaccinia virus, which are well known to extensively modulate the immune response of the host (reviewed in $[29,30]$ ). The galactose oxidase and proteinase inhibitor I4 domains are over-represented in vaccinia virus but absent in cytomegalovirus suggesting that these domains are not used as part of a viral strategy common to these two viruses but are rather specific to vaccinia virus. Similarly, the rhodopsin-like GPCR superfamily is prevalent in cytomegalovirus proteins but absent from vaccinia virus. Cytomegalovirus is known to encode at least four G-protein coupled receptors, which could allow it to modulate and antagonize host signalling pathways [31]. 
Interestingly, protein-protein interaction domains such as SH2, SH3, WW and t-snare domains are conspicuously absent from these viral proteomes (data not shown), indicating that mimicry and modulation of this type of cellular communication mechanism might not be part of the survival strategy of these viruses.

The very high proportion of viral proteins containing one or several eukaryotic targeting motifs and functional domains shows the extensive usage of cellular localization mechanisms and machinery by these viruses. This provides a good indication that eukaryotic protein subcellular localization predictors might perform well on these viruses.

\section{Subcellular localization prediction of viral proteins in host cells}

We used the PSLT human subcellular localization predictor [22] to predict the localization of cytomegalovirus and vaccinia virus proteins and to investigate whether principles of eukaryotic protein localization prediction can be applied to viral proteins. PSLT is a Bayesian network type tool, trained on human sequences, that predicts the subcellular localization of proteins based on the co-occurrence of protein domains, motifs and targeting signals. Table 2 shows the predictions of vaccinia virus proteins whose cellular localization has already been studied experimentally and is available in the literature (the full prediction dataset is available as supplementary material, please see Additional file 1). As shown in Table 2, the localization of most vaccinia virus proteins is well-predicted. The accuracy of PSLT on this dataset can be estimated to be $78 \%$ (proteins localized to more than one compartment are considered to be accurately predicted if at least one predicted compartment agrees with the previous literature annotation). A large proportion (36\%) of these proteins are predicted to be secreted or expressed on the cell surface as integral membrane proteins or membrane anchored proteins. For the most part, this prediction is confirmed in the literature, but it should be considered a conservative estimate, since experimental studies cannot always sample the kinetics of viral protein synthesis and trafficking in all systems under all conditions. This estimate of extracellular and cell surface viral proteins is higher than our estimate of $22 \%$ for human cellular proteins [22], and likely reflects important viral functions that require using the host secretory pathway. Indeed, several of these proteins are known to be involved in modulating the host immune response including secreted proteins that bind chemokines, interferons and interleukin family members [30,32]. Other such proteins are incorporated in the viral envelope. Few or no vaccinia proteins are predicted to localize to the peroxisome, lysosome, ER or Golgi apparatus.
Table 3 shows the PSLT predictions for cytomegalovirus proteins whose cellular localization has already been studied experimentally and is available in the literature (the full prediction dataset is available as supplementary material, please see Additional file 2). The prediction accuracy of PSLT on this dataset is estimated to be $60 \%$ according to the literature. Almost all proteins classified as wrongly predicted according to the literature are annotated as localized in the ER or Golgi apparatus but predicted by PSLT as being on the cell surface. Several of these proteins display characteristics of cell surface or secreted proteins such as the capability to bind MHC class I and class II antigens. However, instead of being secreted, these cytomegalovirus proteins localize to the ER where they bind the MHC antigens, effectively targeting them for degradation and leading to the protection of cytomegalovirus-infected cells from CD8+ and CD4+ T lymphocytes [33]. Many other cytomegalovirus proteins are well-predicted including cell surface receptors, several of which mimic host receptors [34] as well as secreted proteins such as viral chemokine and IL-10 homologues $[35,36]$.

We investigated whether the prediction accuracy of PSLT was correlated with the degree of similarity between the viral proteins and their closest human homologue. The two rightmost columns of Tables 2 and 3 show the closest human homologue from the NCBI RefSeq [37] database for each viral protein, as determined by BLAST [38]. In general, viral proteins that have close human homologues (BLAST e-value <= 1e-10) are accurately predicted by PSLT. The prediction accuracy for these proteins is $100 \%$ for the cytomegalovirus and $91 \%$ for the vaccinia virus. Some viral proteins that do not have close human homologues (BLAST e-value $>1 \mathrm{e}-10$ ) are well-predicted but the overall prediction accuracy of PSLT for these proteins is lower (43\% for cytomegalovirus proteins and 67\% for vaccinia virus proteins). This is consistent with previous analyses which allowed us to show that the prediction accuracy of PSLT is greater when predicting proteins from organisms that are evolutionarily close to those used to train the predictor [22].

\section{Discussion}

The proteomes of vaccinia virus and cytomegalovirus display numerous examples of eukaryotic targeting signals and functional domains, consistent with their evolutionary origin and their extensive usage of many elements of the host cellular machinery. We show here that, as a consequence, the subcellular localization of these viral proteins can be accurately predicted by human protein localization predictors. We used the PSLT predictor which considers the combinatorial presence of domains and targeting signals in human proteins to predict localization. This predictor might be better-suited for this task than other types of localization predictors. Indeed, PSLT specif- 
ically focuses on the localization of human proteins and has been shown to accurately predict the localization of mammalian proteins in general and thus is likely an appropriate choice for the prediction of the localization of viral proteins within human cells. Another advantage of PSLT is that it considers domains and motifs rather than amino acid composition. Many of these domains and motifs are likely involved in interactions with host proteins and should thus more closely resemble human sequences than other regions of the proteins. In fact, several of these domains are believed to have been stolen by these large viruses from host cells [39]. Viral-specific proteins might have evolved to resemble host protein motifs, in order to use mechanisms available in host cells. Not surprisingly, viral proteins that have a high degree of similarity to human proteins are generally better predicted than those that do not have a close human homologue. More extensive research into viral subcellular localization prediction will likely lead to higher prediction accuracy and coverage as the specific non-eukaryotic characteristics of viral proteins can also be exploited to determine their cellular localization. This will likely be particularly important to predict the localization of viral proteins that have little similarity to mammalian proteins.

\section{Conclusion}

This study demonstrates that eukaryotic protein subcellular localization predictors can be used to rapidly annotate specific viral proteomes with a first and reasonably accurate estimate of intracellular localization. The subcellular localization prediction of viral proteins within human cells should be of great utility to the biological community to increase our understanding of the function of these proteins, of their role in the cell and of the consequences of host-pathogen interactions. They might also serve to devise more efficient methods of treatment by rapid identification of targets.

\section{Methods}

28908 human protein sequences were retrieved from the Hera database [27]. These proteins represent all NCBI RefSeq [37] entries currently present in Hera. Cytomegalovirus and vaccinia virus protein sequences were downloaded from UniProt [24]. All sequences were scanned with the different predictors referred to in Table 1 , using the default parameters.

The localization of the viral proteins was predicted using PSLT as previously described [22]. PSLT is a Bayesian network type tool that predicts the subcellular localization of proteins based on the co-occurrence of protein domains, motifs and targeting signals. PSLT was trained on human proteins as described in [22]. In the case of multi-compartmental proteins (proteins that are predicted with high probability to be present in more than one compart- ment), the two most likely compartments were retained. The closest homologue of all viral proteins in Tables 2 and 3 was determined by using BLASTP version 2.2.12 [38] against the NCBI human RefSeq dataset (release 15) [37]. The default parameters of BLASTP were used.

\section{Additional materialAcknowledgements}

\section{Additional File 1}

which contains protein localization predictions for several different strains of the vaccinia virus.

Click here for file

[http://www.biomedcentral.com/content/supplementary/1743422X-3-24-S1.xls]

\section{Additional File 2}

which contains protein localization predictions for several different strains of the human cytomegalovirus

Click here for file

[http://www.biomedcentral.com/content/supplementary/1743422X-3-24-S2.xls]

We wish to thank François Pepin for logistical support. This work was supported by grants to D.Y.T. and M.H. from Genome Quebec/Genome Canada as well as to D.Y.T. from the Canadian Institutes of Health Research (CIHR). M.S.S. is a recipient of a Canada Graduate Scholarship (CGS) Doctoral Award from CIHR.

\section{References}

I. Gershburg E, Marschall M, Hong K, Pagano JS: Expression and localization of the Epstein-Barr virus-encoded protein kinase. J Virol 2004, 78: I2I 40-I2I 46.

2. Miyazaki Y, Takamatsu T, Nosaka T, Fujita S, Martin TE, Hatanaka M: The cytotoxicity of human immunodeficiency virus type $I$ Rev: implications for its interaction with the nucleolar protein B23. Exp Cell Res 1995, 21 9:93-101.

3. Almazan $F$, Tscharke DC, Smith GL: The vaccinia virus superoxide dismutase-like protein (A45R) is a virion component that is nonessential for virus replication. J Virol 200I, 75:7018-7029.

4. Lilley BN, Ploegh HL: A membrane protein required for dislocation of misfolded proteins from the ER. Nature 2004, 429:834-840.

5. Wiertz EJ, Tortorella D, Bogyo M, Yu J, Mothes W, Jones TR, Rapoport TA, Ploegh HL: Sec6I-mediated transfer of a membrane protein from the endoplasmic reticulum to the proteasome for destruction. Nature 1996, 384:432-438.

6. Atalay R, Zimmermann A, Wagner M, Borst E, Benz C, Messerle M, Hengel $\mathrm{H}$ : Identification and expression of human cytomegalovirus transcription units coding for two distinct Fcgamma receptor homologs. J Virol 2002, 76:8596-8608.

7. Boya P, Pauleau AL, Poncet D, Gonzalez-Polo RA, Zamzami N, Kroemer G: Viral proteins targeting mitochondria: controlling cell death. Biochim Biophys Acta 2004, 1659:178-189.

8. Everett $\mathrm{H}$, McFadden $\mathrm{G}$ : Viruses and apoptosis: meddling with mitochondria. Virology 200I, 288:I-7.

9. da Fonseca FG, Silva RL, Marques JT, Ferreira PC, Kroon EG: The genome of cowpox virus contains a gene related to those encoding the epidermal growth factor, transforming growth factor alpha and vaccinia growth factor. Virus Genes 1999, 18:151-160.

10. Upton C, Mossman K, McFadden G: Encoding of a homolog of the IFN-gamma receptor by myxoma virus. Science 1992, 258:1369-1372 
II. Donnes P, Hoglund A: Predicting protein subcellular localization: past, present, and future. Genomics Proteomics Bioinformatics 2004, 2:209-2I5.

12. Feng ZP: An overview on predicting the subcellular location of a protein. In Silico Biol 2002, 2:291-303.

13. Reinhardt $A$, Hubbard $T$ : Using neural networks for prediction of the subcellular location of proteins. Nucleic Acids Res 1998, 26:2230-2236.

14. Hua S, Sun Z: Support vector machine approach for protein subcellular localization prediction. Bioinformatics 200I, | 7:72|-728.

15. Chou KC: Prediction of protein cellular attributes using pseudo-amino acid composition. Proteins 200I, 43:246-255.

16. Bendtsen JD, Nielsen H, von Heijne G, Brunak S: Improved prediction of signal peptides: SignalP 3.0. J Mol Biol 2004, 340:783-795.

17. Emanuelsson O, Nielsen H, Brunak S, von Heijne G: Predicting subcellular localization of proteins based on their $\mathbf{N}$-terminal amino acid sequence. J Mol Biol 2000, 300:1005-10I6.

I8. Marcotte EM, Xenarios I, van Der Bliek AM, Eisenberg D: Localizing proteins in the cell from their phylogenetic profiles. Proc Natl Acad Sci U S A 2000, 97:12115-12120.

19. Lu Z, Szafron D, Greiner R, Lu P, Wishart DS, Poulin B, Anvik J, Mac donell C, Eisner R: Predicting subcellular localization of proteins using machine-learned classifiers. Bioinformatics 2004, 20:547-556

20. Nakai K, Kanehisa M: A knowledge base for predicting protein localization sites in eukaryotic cells. Genomics 1992, | 4:897-9| |.

21. Drawid A, Gerstein M: A Bayesian system integrating expression data with sequence patterns for localizing proteins: comprehensive application to the yeast genome. J Mol Biol 2000, 301:1059-1075.

22. Scott MS, Thomas DY, Hallett MT: Predicting subcellular localization via protein motif co-occurrence. Genome Res 2004, | 4:1957-1966.

23. Hoglund A, Donnes P, Blum T, Adolph HW, Kohlbacher O: MultiLoc: prediction of protein subcellular localization using $\mathbf{N}$. terminal targeting sequences, sequence motifs, and amino acid composition. Bioinformatics 2006.

24. Bairoch A, Apweiler R, Wu CH, Barker WC, Boeckmann B, Ferro S, Gasteiger E, Huang H, Lopez R, Magrane M, Martin MI, Natale DA, O'Donovan C, Redaschi N, Yeh LS: The Universal Protein Resource (UniProt). Nucleic Acids Res 2005, 33:DI54-9.

25. Maggioni C, Braakman I: Synthesis and quality control of viral membrane proteins. Curr Top Microbiol Immunol 2005, 285: $175-198$.

26. Chazal N, Gerlier D: Virus entry, assembly, budding, and membrane rafts. Microbiol Mol Biol Rev 2003, 67:226-237.

27. Scott M, Lu G, Hallett M, Thomas DY: The Hera database and its use in the characterization of endoplasmic reticulum proteins. Bioinformatics 2004, 20:937-944.

28. Mulder NJ, Apweiler R, Attwood TK, Bairoch A, Barrell D, Bateman A, Binns D, Biswas M, Bradley P, Bork P, Bucher P, Copley RR, Courcelle E, Das U, Durbin R, Falquet L, Fleischmann W, Griffiths-Jones S, Haft D, Harte N, Hulo N, Kahn D, Kanapin A, Krestyaninova M Lopez R, Letunic I, Lonsdale D, Silventoinen V, Orchard SE, Pagni M, Peyruc D, Ponting CP, Selengut JD, Servant F, Sigrist CJ, Vaughan R, Zdobnov EM: The InterPro Database, 2003 brings increased coverage and new features. Nucleic Acids Res 2003, 3 I:3 I5-3 I8.

29. Mocarski ES]: Immune escape and exploitation strategies of cytomegaloviruses: impact on and imitation of the major histocompatibility system. Cell Microbiol 2004, 6:707-7I7.

30. Smith GL, Symons JA, Alcami A: Immune modulation by proteins secreted from cells infected by vaccinia virus. Arch Virol Suppl 1999, I 5: I II-129.

31. Stropes MP, Miller WE: Signaling and regulation of G-protein coupled receptors encoded by cytomegaloviruses. Biochem Cell Biol 2004, 82:636-642.

32. Dunlop LR, Oehlberg KA, Reid J], Avci D, Rosengard AM: Variola virus immune evasion proteins. Microbes Infect 2003 5:1049-1056.

33. Huber MT, Tomazin R, Wisner T, Boname J, Johnson DC: Human cytomegalovirus US7, US8, US9, and US 10 are cytoplasmic glycoproteins, not found at cell surfaces, and US9 does not mediate cell-to-cell spread. J Virol 2002, 76:5748-5758.
34. Michelson S: Consequences of human cytomegalovirus mimicry. Hum Immunol 2004, 65:465-475.

35. Penfold ME, Dairaghi DJ, Duke GM, Saederup N, Mocarski ES, Kemble GW, Schall TJ: Cytomegalovirus encodes a potent alpha chemokine. Proc Natl Acad Sci U S A 1999, 96:9839-9844.

36. Kotenko SV, Saccani S, Izotova LS, Mirochnitchenko OV, Pestka S Human cytomegalovirus harbors its own unique IL-I0 homolog (cmvIL- I 0). Proc Natl Acad Sci U S A 2000, 97: 1695-I 700

37. Pruitt KD, Tatusova T, Maglott DR: NCBI Reference Sequence (RefSeq): a curated non-redundant sequence database of genomes, transcripts and proteins. Nucleic Acids Res 2005, 33:D50I-4

38. Altschul SF, Madden TL, Schaffer AA, Zhang J, Zhang Z, Miller W, Lipman DJ: Gapped BLAST and PSI-BLAST: a new generation of protein database search programs. Nucleic Acids Res 1997, 25:3389-3402.

39. Chensue SW: Molecular machinations: chemokine signals in host-pathogen interactions. Clin Microbiol Rev 200I, I 4:82 I-835.

40. Small I, Peeters N, Legeai F, Lurin C: Predotar: A tool for rapidly screening proteomes for $\mathbf{N}$-terminal targeting sequences. Proteomics 2004, 4: I58I-I590.

4I. Krogh A, Larsson B, von Heijne G, Sonnhammer EL: Predicting transmembrane protein topology with a hidden Markov model: application to complete genomes. J Mol Biol 200I, 305:567-580.

42. Fankhauser N, Maser P: Identification of GPI anchor attachment signals by a Kohonen self-organizing map. Bioinformatics 2005, $21: 1846-1852$

43. Hulo N, Sigrist CJ, Le Saux V, Langendijk-Genevaux PS, Bordoli L, Gattiker A, De Castro E, Bucher P, Bairoch A: Recent improvements to the PROSITE database. Nucleic Acids Res 2004, 32:DI34-7.

44. Cokol M, Nair R, Rost B: Finding nuclear localization signals. EMBO Rep 2000, I:4I I-4I5.

45. Lorenzo MM, Galindo I, Griffiths G, Blasco R: Intracellular localization of vaccinia virus extracellular enveloped virus envelope proteins individually expressed using a Semliki Forest virus replicon. J Virol 2000, 74: I0535-10550.

46. Sanderson CM, Parkinson JE, Hollinshead M, Smith GL: Overexpression of the vaccinia virus $\mathrm{A} 38 \mathrm{~L}$ integral membrane protein promotes $\mathrm{Ca2+}$ influx into infected cells. J Virol 1996, 70:905-9|4

47. Gardner JD, Tscharke DC, Reading PC, Smith GL: Vaccinia virus semaphorin A39R is a $\mathbf{5 0 - 5 5} \mathbf{~ k D a}$ secreted glycoprotein that affects the outcome of infection in a murine intradermal model. J Gen Virol 200I, 82:2083-2093.

48. Wilcock D, Duncan SA, Traktman P, Zhang WH, Smith GL: The vaccinia virus A4OR gene product is a nonstructural, type II membrane glycoprotein that is expressed at the cell surface. J Gen Virol 1999, 80 ( Pt 8):2। 37-2148.

49. Kettle S, Blake NW, Law KM, Smith GL: Vaccinia virus serpins BI3R (SPI-2) and B22R (SPI-I) encode $M(r) 38.5$ and $40 K$, intracellular polypeptides that do not affect virus virulence in a murine intranasal model. Virology $1995,206:|36-| 47$.

50. Danescu J, Werenskiold AK: Post-transcriptional inhibition of the interleukin-I binding protein B I 5R of vaccinia virus after coexpression of the related TI protein. FEBS Lett 1995, 367:89-92.

51. Colamonici OR, Domanski P, Sweitzer SM, Larner A, Buller RM: Vaccinia virus $B$ I $8 R$ gene encodes a type I interferon-binding protein that blocks interferon alpha transmembrane signaling. J Biol Chem 1995, 270:15974-15978.

52. Meiser A, Sancho C, Krijnse Locker J: Plasma membrane budding as an alternative release mechanism of the extracellular enveloped form of vaccinia virus from HeLa cells. J Virol 2003 , 77:993।-9942.

53. Engelstad $M$, Smith GL: The vaccinia virus 42-kDa envelope protein is required for the envelopment and egress of extracellular virus and for virus virulence. Virology 1993, 194:627-637.

54. Symons JA, Adams E, Tscharke DC, Reading PC, Waldmann H, Smith GL: The vaccinia virus CI 2 L protein inhibits mouse IL- I 8 and promotes virus virulence in the murine intranasal model. J Gen Virol 2002, 83:2833-2844.

55. Pires de Miranda M, Reading PC, Tscharke DC, Murphy BJ, Smith GL: The vaccinia virus kelch-like protein $C 2 L$ affects calciumindependent adhesion to the extracellular matrix and 
inflammation in a murine intradermal model. J Gen Virol 2003, 84:2459-247।.

56. Maa JS, Rodriguez JF, Esteban M: Structural and functional characterization of a cell surface binding protein of vaccinia virus. J Biol Chem 1990, 265:I569-1577.

57. Beaud G: Vaccinia virus DNA replication: a short review. Biochimie 1995, 77:774-779.

58. Hu X, Wolffe EJ, Weisberg AS, Carroll LJ, Moss B: Repression of the A8L gene, encoding the early transcription factor 82kilodalton subunit, inhibits morphogenesis of vaccinia virions. J Virol 1998, 72: 104-I I2.

59. Yuwen H, Cox JH, Yewdell JW, Bennink JR, Moss B: Nuclear localization of a double-stranded RNA-binding protein encoded by the vaccinia virus E3L gene. Virology 1993, 195:732-744.

60. Reckmann I, Higley S, Way M: The vaccinia virus FI7R protein interacts with actin. FEBS Lett 1997, 409:|4|-| 46.

61. Brown CK, Turner PC, Moyer RW: Molecular characterization of the vaccinia virus hemagglutinin gene. J Virol 1991, 65:3598-3606.

62. Bradley RR, Terajima M: Vaccinia virus KIL protein mediates host-range function in RK-I3 cells via ankyrin repeat and may interact with a cellular GTPase-activating protein. Virus Res 2005.

63. Turner PC, Baquero MT, Yuan S, Thoennes SR, Moyer RW: The cowpox virus serpin SPI-3 complexes with and inhibits urokinase-type and tissue-type plasminogen activators and plasmin. Virology 2000, 272:267-280.

64. Xiang Y, Simpson DA, Spiegel J, Zhou A, Silverman RH, Condit RC: The vaccinia virus AI8R DNA helicase is a postreplicative negative transcription elongation factor. J Virol 1998, 72:7012-7023

65. Kim HS, Lee YH, Min DS, Chang JS, Ryu SH, Ahn BY, Suh PG: Tyrosine phosphorylation of phospholipase C-gamma I by vaccinia virus growth factor. Virology 1995, 214:2।-28.

66. Prichard MN, Lawlor H, Duke GM, Mo C, Wang Z, Dixon M, Kemble G, Kern ER: Human cytomegalovirus uracil DNA glycosylase associates with ppUL44 and accelerates the accumulation of viral DNA. Virol J 2005, 2:55.

67. Cosman D, Fanger N, Borges L, Kubin M, Chin W, Peterson L, Hsu ML: A novel immunoglobulin superfamily receptor for cellular and viral MHC class I molecules. Immunity 1997, 7:273-282.

68. Fraile-Ramos A, Pelchen-Matthews A, Kledal TN, Browne $H$ Schwartz TW, Marsh M: Localization of HCMV UL33 and US27 in endocytic compartments and viral membranes. Traffic 2002, 3:218-232

69. Ogawa-Goto K, Irie $\mathrm{S}$, Omori A, Miura $\mathrm{Y}$, Katano $\mathrm{H}$, Hasegawa $\mathrm{H}$, Kurata T, Sata T, Arao $Y$ : An endoplasmic reticulum protein p I 80, is highly expressed in human cytomegalovirus-permissive cells and interacts with the tegument protein encoded by UL48. J Virol 2002, 76:2350-2362.

70. Bradshaw PA, Duran-Guarino MR, Perkins S, Rowe JI, Fernandez J, Fry KE, Reyes GR, Young L, Foung SK: Localization of antigenic sites on human cytomegalovirus virion structural proteins encoded by UL48 and UL56. Virology 1994, 205:32I-328.

71. Appleton BA, Loregian A, Filman DJ, Coen DM, Hogle JM: The cytomegalovirus DNA polymerase subunit UL44 forms a C clamp-shaped dimer. Mol Cell 2004, 1 5:233-244.

72. Michel D, Pavic I, Zimmermann A, Haupt E, Wunderlich K, Heuschmid M, Mertens T: The UL97 gene product of human cytomegalovirus is an early-late protein with a nuclear localization but is not a nucleoside kinase. J Virol 1996, 70:6340-6346.

73. Lee S, Park B, Ahn K: Determinant for endoplasmic reticulum retention in the luminal domain of the human cytomegalovirus US3 glycoprotein. J Virol 2003, 77:2147-2I56.

74. Jones TR, Wiertz EJ, Sun L, Fish KN, Nelson JA, Ploegh HL: Human cytomegalovirus US3 impairs transport and maturation of major histocompatibility complex class I heavy chains. Proc Natl Acad Sci U S A 1996, 93: I 1327-1 I 333.

75. Lehner PJ, Karttunen JT, Wilkinson GW, Cresswell P: The human cytomegalovirus US6 glycoprotein inhibits transporter associated with antigen processing-dependent peptide translocation. Proc Natl Acad Sci U S A 1997, 94:6904-6909.

\section{Publish with Biomed Central and every} scientist can read your work free of charge

"BioMed Central will be the most significant development for disseminating the results of biomedical research in our lifetime. "

Sir Paul Nurse, Cancer Research UK

Your research papers will be:

- available free of charge to the entire biomedical community

- peer reviewed and published immediately upon acceptance

- cited in PubMed and archived on PubMed Central

- yours - you keep the copyright
BioMedcentral 